\title{
Historein
}

Vol 15, No 2 (2015)

Historein 15/2 (2015)

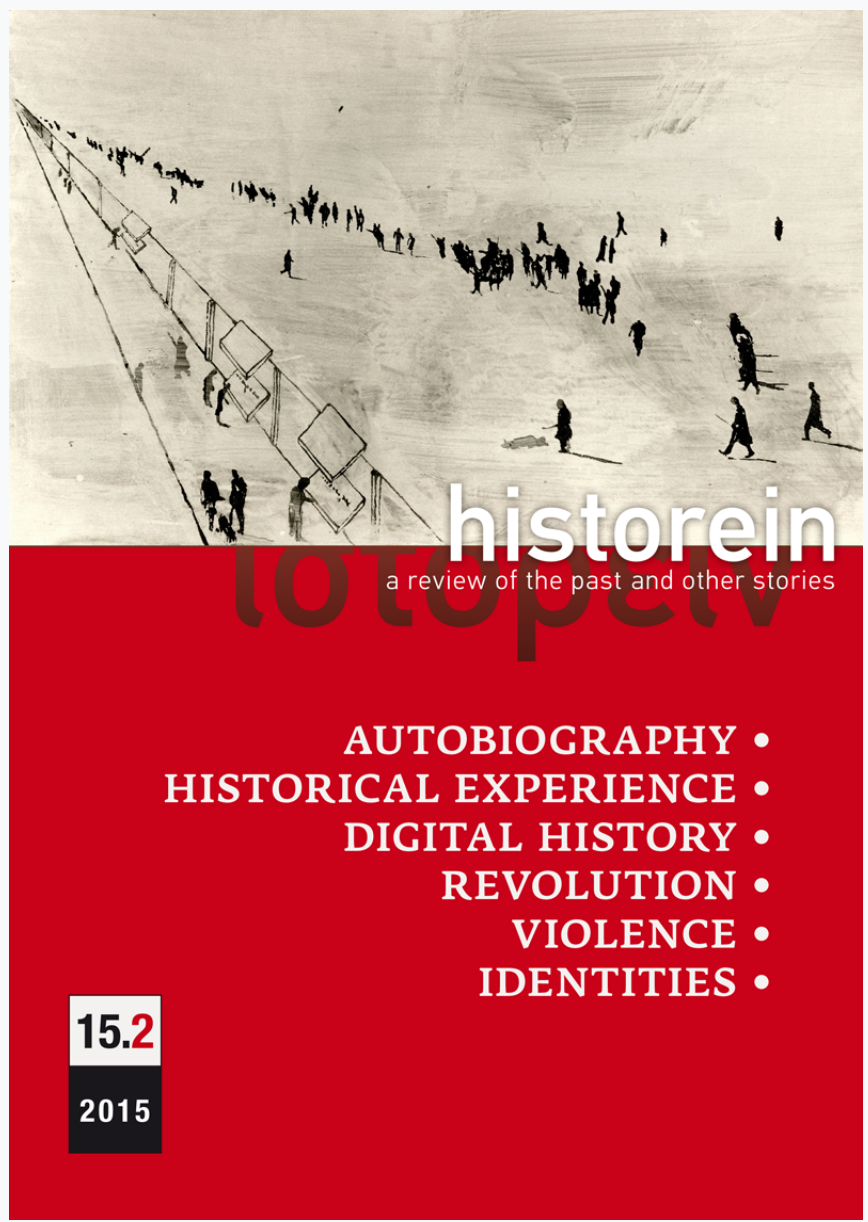

Golden Dawn through a psychosocial lens

Thalia Dragonas

doi: $10.12681 /$ historein.317

Copyright $\odot 2015$, Thalia Dragonas

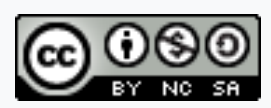

This work is licensed under a Creative Commons Attribution-NonCommercialShareAlike 4.0.

To cite this article:

Dragonas, T. (2016). Golden Dawn through a psychosocial lens. Historein, 15(2), 56-67.

https://doi.org/10.12681/historein.317 


\section{Golden Dawn \\ through \\ a psychosocial lens}

The extreme right in Europe may display a set of common features but in many respects there are marked differences between the various like-minded movements. Despite the fact that in the 1980s and 1990s Europe's rightwing radicals and populists started to make electoral gains, similar Greek political movements remained absolutely marginal. It was in 2007, that we started to witness the ascent of the extreme right, when the Popular Orthodox Rally (Laos) entered the Greek parliament. Some years later, from 2010 to 2012, with the deepening of the financial crisis, the Golden Dawn party leapt from the margins to the centre stage of the political arena of crisis-ridden Greece, to the point of gaining third place in the January 2015 election.

Not only political analysts but also a large segment of society are having difficulty in explaining how a party that openly supports national socialism, adopts symbols such as the swastika and the Hitler salute and operates on the basis of militia practices has gained such popularity.

Thalia Dragonas

University of Athens
What is even more disquieting is that extreme rightwing ideology has attracted voters from established parties. Disguised under a populist anticapitalist, antiglobalisation, Eurosceptic and antimulticulturalist cloak, the exclusionary far-right, racist (in the most primitive sense of biological racism), antisemitic, ethnocentric, religious-fundamentalist, xenophobic and homophobic discourse has proved to have appeal across the entire political spectrum. While Golden Dawn belongs to an extremist, fascist variant of the far right, and the corresponding discourse in the rest of the parties belongs to an ethnocentric, populist version, the underlying ideology is much the same. 
Thus a number of questions arise: how can one understand this widespread, extreme-right thinking? How can one justify that Greek voters trust a neo-Nazi party? And how can one explain that the supporters of Golden Dawn legitimate political violence?

Dissecting this extremism requires a multifocal analysis. Analytically, the various factors implicated are distinct and each one has its own logic. In real life, however, they are often interconnected and influence each other in a multitude of combinations. Our task as social scientists is to disentangle them, reveal their respective rationales and recognise the way they are articulated on the sociopolitical and intrapsychic levels.

\section{The economic and sociopolitical dimension}

Academic and lay analysts have discussed the crisis of the past almost six years mainly in economic terms. Yet the crisis exhibits other structural dimensions. The financial devastation wreaked by the economic crisis has been accompanied by violent downward mobility, severe disruption of social bonds, a wedge in Greek politics that has reduced the political debate into a pro- and antimemorandum stance, and political impoverishment expressed in the rise of national populism.

Admittedly the economic dimension is the most obvious aspect of the crisis, one of the longest and most severe in Greece's modern history. The harshness of many of the fiscal policies that have been adopted since 2010 pushed working-class and lower-middle-class people into destitution; the unemployment rate reached $28 \%$, leaving 3.5 million people working to support more than 4.5 million who are unemployed or inactive. The austerity measures and the recession that followed have generated considerable anxiety.

The long-standing inability for recovery eroded people's confidence in political parties, politicians and European institutions. The lack of public confidence in politicians pinnacled in 2011 with the Indignados movement (the radical left and far right together) occupying Syntagma Square in central Athens shouting slogans against the parliament and politicians. In 2012, the small conservative party Recreate Greece was promising "politics with no politicians". Trust in political institutions did not fare any better in the following years. In a November 2014 survey by Public Issue on the institutions trusted by the Greeks, $80 \%$ responded they trusted the army and $70 \%$ the police, while only $26 \%$ trusted parliament and $11 \%$ the political parties. 'The air of optimism and the boosting of trust in political institutions brought about with the January 2015 elections lasted only briefly. After almost a year of the coalition government of the radical left and populist right, the same lack of trust, witnessed a year earlier, was corroborated. Interestingly, trust in the army rose to $87 \%$ and in parliament and political parties remained very low $\left(27 \%\right.$ and $10 \%$, respectively). ${ }^{2} \mathrm{~A}$ vertiginous decline in trust in the European Union has also taken place as anger towards European institutions grew. In 2014, according to Eurobarometer, $81 \%$ of Greeks did not trust the European Union, the highest percentage among all EU members ${ }^{3}$ while up until 2004 Greeks harboured the most pro-European attitudes. ${ }^{4}$ Rejection of the political system and the delegitimisation of the parliamentary form of government is characteristic of Golden Dawn discourse. 
A third circumstance that is often linked to the rise of the extreme right is the mass influx of migrants in what was up until recently a relatively homogeneous country. Governments have so far dealt with immigration with no integrated strategy, no consistent immigration policy and no proper asylum service. While immigration indeed burdens Greece, it constitutes a big challenge involving a significant shift in public discourse and policies concerning integration, and more generally, the politics of interculturalism. In the person of the migrant, radical right-wing ideology found its preferential adversary. The Popular Orthodox Rally (Laos) party entered parliament by championing the principle of "national priority" and, in line with that principle, called for the immediate deportation of all illegal immigrants. As far as Golden Dawn is concerned, it supports the notion that Greece is an ethno-culturally homogeneous nation-state, defines nationality in terms of "race, blood and ancestry" and considers immigrants as the biggest threat to the racial homogeneity of the nation. Yet, despite the popular belief that Golden Dawn flourishes in geographical areas with the highest concentration of immigrant population, this is not actually the case. According to Alexis Ikonimidis, neither the results of the 2012 general election, when Golden Dawn first entered parliament, nor the European Parliament elections in 2014, when Golden Dawn reached $9.4 \%$, confirm that its supporters come from regions where the percentage of immigrants is the highest. ${ }^{5}$ While in the 2014 elections the national mean of Golden Dawn votes was $9.39 \%$, in Laconia, a traditionally rightwing, royalist constituency which by no means has the highest immigration concentration, the extreme right obtained $15.45 \%$. As Ikonimidis contends, "it is not the physical presence but the notion of the immigrant that affects consciousness and behaviours - and when physical presence is restricted even more so". The voters' turn to Golden Dawn is due to structural and cultural factors such as the destruction of local economic activity, the violent downward mobility of the middle and lower classes, chronic unemployment, poverty, the lack of social services as well as deep-rooted extreme rightwing ideology.

Thus, the crisis in Greece has undoubtedly played a big role in explaining, at the sociopolitical level, how extreme-right populism turned into a legitimate ideology. There are indeed a number of developments that lie behind the rise of Golden Dawn. Yet, the crisis has also served as a trigger that brought to the fore latent extreme rightwing potential. In their relatively recent publications, Aristos Doxiadis and Manos Matsaganis, as well as Anna Frangoudaki, underline that the rise of Golden Dawn was not as sudden a phenomenon as many commentators suggest. ${ }^{6}$ The party's set of beliefs are shared, in one way or another, by a wide percentage of Greeks. Frangoudaki cites the educational system as the example par excellence responsible for the production and reproduction of the ethno-national populism pervading extreme-right ideology. Education has remained fixated on an outdated national myth of exceptionalism, imbued with a strong dose of nostalgia for the nation-building struggles that belong to another historical era. It cultivates xenophobia and isolationism and does not encourage responsible civic action. These authors maintain that Golden Dawn's electoral success has rested, to a considerable extent, on a widely shared worldview which has dominated public discourse since the 1950s and which cuts across the political spectrum. 


\section{Intrapsychic and interpersonal mechanisms}

The main focus of this article is how the above-mentioned developments translate into intrapsychic and interpersonal mechanisms to explain the political phenomenon of Golden Dawn. I will draw on psychoanalytic concepts that may be useful for an understanding of how the crisis has functioned as a mechanism for the production and control of individual and collective subjectivities.

Many cultural commentators have documented persuasively the complexity and difficulty of tying the individual psyche to culture or society and the reductionist dangers in doing so. I am fully aware of such dangers. However, the consciously articulated ideologies that tend to justify behaviour, such as the one manifested by Golden Dawn and its supporters, often seem directly, without much symbolic transformation or elaboration, to express exactly what psychoanalysis describes as the individual unconscious motivations and internal constructions that lead to far-right extremism. That is, this ideology seems particularly expressive of unconscious life. In this sense, it may well serve as a kind of personal symbol or transitional concept, linking what comes psychodynamically from within the individual to a similar formulation that comes culturally from without.?

The multifaceted crisis, briefly described earlier, has created immense insecurity and given rise to feelings of desperation, fear and anger. It has not only deprived people of material sustenance but has also created a sense of failure, shame, guilt, humiliation, as well as a loss of dignity, self-respect and pride. ${ }^{8}$ The crisis has caused damage to one's identity or sense of self. It is no coincidence that one of the most appealing arguments used by the current government during the summer 2015 referendum, and which enjoyed unprecedented popularity, was that it was fighting for the restitution of the damaged national dignity.

As described earlier, a threatening reality looms large and the danger that individuals perceive reality to pose for them must not be underestimated. The current shaky financial and political situation, whereby the future of Greece is in the hands of its creditors, constitutes a site of struggle, a contest between self-control and being controlled by others. Thus, the threat reality poses refers to a sense of existence outside one's own subjective control.

"Reality" is a tricky concept for social scientists because they know better than anybody else that what is perceived as "real" is socially constructed as a result of the articulation between the internal and external worlds. The relationship between these worlds is a dynamic one. It involves the processes of internalisation (by activating the mechanisms of identification and incorporation) and externalisation (by mobilising, especially projection) through which the individual attempts to use what is outside to achieve psychic ends.?

Institutions and groups serve a psychic purpose in addition to, or even in the place of, the ostensible purpose with which they are normally associated. That is, they have a power to create a substitute reality. This substitute reality has an important quality: it carries the agreement of the group. This implies that reality can be whatever the group wants it to be. However, this creation of reality is also the destruction of reality. In other words, the creation of reality by and for the group is meant to displace any reality that might exist for the individual outside the group. ${ }^{10}$ The power of groups 
and institutions, then, is that they can dismiss, and even destroy reality, so far as reality exists apart from and stands against group consciousness. The personal boundaries loosen up and individuals get incorporated in the group. They are stripped from their subjectivity and are absorbed by a large collective "false self". I claim that Golden Dawn does exactly that. It offers a substitute reality, sealed by the agreement of the group, and appeases the threatening reality.

\section{The transcendent group}

The term "group" is not used in the classical sociopsychological sense of a face-to-face encounter between individuals. The groups that construct social reality are more abstract, even ideal, such as ethnic groups, communities, political parties and so on. It is the very distance rather than the face-to-face proximity that will ensure a transcendent reality in the individual's life. A transcendent group has the power to instantiate modes of conduct and interaction, and in this sense, to create social reality. It has a quality of enduring, independent of the particular individuals that compose it at a particular moment in time. In a transcendent group there is an atemporal and aspatial dimension of uninterrupted continuity.

Transcendence frees the group from its material reality no matter if members may represent it in material manifestations and symbolical physical objects. The group invests in memories, myths, rituals and culturally laden dreams in order to retain the constructed reality as an abstract, mythical ideal. Analyses that have used a psychoanalytic interpretation of neo-Nazism " comment that the ritual practices adopted are a prerequisite in sustaining the myth: symbols, attire, gestures, flags and parades are all rites of enhancing group loyalty.

The uniform attire in black and boots, the party logo on the back of T-shirts and the swastika-like symbol tattooed on the arm and chest, the Nazi salute, the military step and the rhythmic battle cries all form part of the large-scale rituals of Golden Dawn supporters, feeding the enactment of body politics. The ceremonies held at historical sites, reminiscent of large-scale Nazi public events, commemorate, to use Vamık Volkan's term, national "chosen glories". Corporeal participation, sensory stimulation and manipulation reinforce the legitimacy of the group and its identity patterns. ${ }^{12}$ This is consistent with Étienne Balibar's argument that national community and imagination are configured through a network of apparatuses and practices that form the individual as homo nationalis. ${ }^{13}$

Golden Dawn supporters, bearing huge torches and standing aligned in rows at ceremonial events, bring to mind the Nazi torchlight parades. Klaus Hesse, the curator of the exhibition "The path to dictatorship" in Berlin's Topography of Terror museum, ${ }^{14}$ makes an interesting remark regarding the special relationship of flame and fire in Nazi iconography, which can be transferred to the analysis of Golden Dawn. A flame, he says, sheds equal light on the faces of all those standing around it, symbolising social equality according to the ideology of the "folk community". In all totalitarian regimes, homogeneity aims, among other things, at the eradication of class differences. It is this social equality that is probably sought after by Golden Dawn supporters, who are, in higher per- 
centages than the average voter, in precarious employment situations, unemployed and of low educational background. ${ }^{15}$

\section{Fantasies of omnipotence}

Why does the individual imagine that the group has a special power to create reality, especially if the individual does not? The answer to this question involves the fantasy of omnipotence that exists at the centre of the notion of the creation of reality - that is, of a substitute reality. The primal fantasy at work is that we can create reality by wishing and willing it.

The group, via the mechanism of projection, is the repository of the omnipotent fantasies of its members, who imagine that they can be safely experienced if they are displaced onto the group. The group has the power to destroy or to create reality. As Otto Kernberg would say, those who seek the alternative reality offered by a group or an institution exhibit a "chronic overdependence on external objects" rather than developing an ebb and flow between subject and object roles. ${ }^{16}$ The lack of freedom is obvious. Rationalism, independent thinking, free choice, decision making and rational behaviour are all repelled. Yet, this impoverishment of subjective experience has secondary gains - that is, a kind of power, or the illusion of power over the world and the enlistment of others in one's effort to deal with anxiety. In other words, subjectivity is transferred from the individual to the group. In our case, the crisis-ridden, vulnerable individual turns to Golden Dawn in the expectation and hope that the party will have the power to create a new, more promising reality.

These fantasies are channelled through the mechanism of projection (one of the most primal defence mechanisms) onto the leader of the group, Nikos Michaloliakos, who is closely identified with the history of the party. His title, "Supreme Leader", is a signifier full of meaning. Submission to the leader, the request that "everybody stand" when he appeared publicly after the May 2012 election for his first press conference and his MPs standing to attention when he gave his maiden speech in parliament are all indicative of the fantasies of omnipotence the followers project onto the party leader.

As it has often been indicated, the idealisation of party leaders is a constant characteristic and an eternal danger of totalitarian systems. The source of this making is the creation of a collective false self. Under some unauthentic identification, the collective false self tends to re-create an inauthentic artificial partner to identify with: to make "likenesses" to create artificial objects such as ideologies, to give them false life and power, to attribute to them god-like adjectives, to worship them, until these idols, finally, destroy any authentic life. Totalitarian systems are nourished by the psychological foundations of the collective false self, by the false "we". ${ }^{17}$

The leader connects the members to the party with a moral significance. What makes the group an ideal is the attachment of moral judgment to its concrete way of being. In the absence of such, moral judgment remains contingent, even ephemeral. The "Supreme Leader" mobilises his followers by resorting to moral arguments. One of the notorious scenes in Golden Dawn's history is 
Michaloliakos extending one arm in front of a massive audience saying: "in this rotten state, in this state of bribery and corruption ... a star is rising, a bright light ... we have been called Nazi but we have never been accused of being thieves ... these hands may salute in this way [and he raises his hand in a Nazi salute] but they are clean hands, they are not dirty, they have not stolen." ${ }^{18}$

\section{Use and abuse of history}

While communication in the small group is carried out by verbal or nonverbal exchange, in the abstract, transcendent group discourse takes its place - that is, the language of ideology. Ideology justifies the particular interests of a group, albeit in a misleading way because historicity and contingency are presented as natural and unavoidable. The element of power in the discourse of ideology is its self-fulfilling nature and the enforcement of taxonomies of inclusion and exclusion.

History is one of the preferential materials for the establishment of ideology that cements the psychic life of the "group matrix", as SH Foulkes would say.

The constant use of history by Golden Dawn, the provision of history classes to young children, the selection of monuments for the mobilisation of followers and the commemoration services for national events all make use of what Volkan calls "chosen glories and chosen traumas" that serve to draw boundaries between inclusion and exclusion. ${ }^{19}$ The power of "chosen glories and chosen traumas" in reinforcing connectedness is huge. They are empty vessels that can contain anything. They are empty signifiers. "Chosen glories and chosen traumas" are there to be used and abused.

"Chosen glories" may well serve as a compensatory mechanism for the felt national shame. Extreme rightwing discourse speaks about a humiliated Greek people who experience a loss of continuity with the glorious past. I have mentioned elsewhere that Greek national identity sees the damage it felt as a narcissistic injury bringing about painful feelings of shame and humiliation that call for narcissistic reparation. ${ }^{20}$ Stylianidis makes the same point, supporting that those who are fascinated by Golden Dawn discourse are the ones who experience shame as members of a humiliated Greek people that is internationally exposed, accused of living a lawless, irresponsible and slothful life. ${ }^{21}$ Shame may lead to an unending spiral of shame, anger and aggression. The need for reparation among Golden Dawn followers is expressed through the narcissistic identification with the powerful leader, who promises to restore the dignity of the Greek nation. The use and abuse of history serves this narcissistic rage, hatred and associated violence. "When we hate, we do not hate as individuals. We hate in the first person plural."22

\section{The denigration and extinction of the 'other'}

As Freud has taught us, group cohesion in its most primitive sense is achieved through the emotional tie and the identificatory "love" between the leader and his followers and through negative 
identification and hatred towards all those who are out-group members. ${ }^{23}$ With collective denigration or even extinction of the "other", negative feelings and impulses are displaced towards the out-group. The in-group and the self as part of it are idealised and the stranger who is outside is demonised. The in-group is "good"; the out-group "bad".

Melanie Klein describes this primitive defence mechanism as splitting, whereby individuals keep "bad" and "good" objects separate. ${ }^{24}$ In this "paranoid-schizoid position" there is splitting of both self and object into good and bad, with little or no integration between them. Klein considered splitting to be characteristic of the earliest month of life whereby the infant splits both its ego and its object and projects its loving and hating feelings into separate parts of the mother, with the result that the maternal object is divided into a bad part, which is felt to be persecutory and is hated, and a good part, which is felt to be loving and gratifying.

Paranoid-schizoid mental states are not necessarily pathological. Such primitive emotions may surface in anxiety situations throughout life whereby splitting keeps the good and loving parts of experience separate from the bad and hateful ones. Splitting is often followed by a second defence - projection. Anxieties observed in a group may be located in individuals, or, in some sense, may be the joint property of several members, or of the group as a whole. Defence mechanisms such as splitting and projection are set in motion and show how the external world of other people and the internal world of the self can flow into each other. 25 "Us" groups project unwanted aspects of ourselves into "them" groups. As a consequence, the "them" group comes to be experienced as embodying the negative aspects that have been projected onto and into them and through this mechanism "them" come to be devalued and denigrated. This is not a static operation. It is a continuous process in the making and is adopted in the context of large groups and institutions such as the nation, religion, political parties, football teams and so on.

In today's circumstances there exist, as I contended earlier, widely shared insecurity, fear and anxiety. Stelios Stylianidis goes as far to describe such feelings, in clinical terms, as a form of psychotic anxiety. ${ }^{26}$ Thus, on a collective level, paranoid mechanisms are set in motion and a primal discharge of non-elaborated anxiety and fear takes place. In order to avoid a narcissistic breakdown that leaves one totally exposed, the threat from within is projected onto "others", who function as receptors of one's negative aspects and offer the precious service of stabilising the group. The non-projected good parts strengthen even more the group under pressure. These take the form of grandeur, a sense of self-sufficiency, belief in the exceptionalism of the Greek nation and the Greek people, which abound, often with incomparable vulgarity, in Golden Dawn's political rhetoric and everyday discourse. This operates as a reparative defence that restores feelings of inferiority.

Based on Freud's concept of psychological projection, Klein goes a step further and introduced another primitive mechanism - that of projective identification. This is a process that reduces the boundaries between individuals and creates powerful unconscious persuasive effects, forcing people to take in and experience states of mind that originate in others. The "other" becomes the very embodiment of projection. Projective identification is at the heart of nationalism and racism. On a fantasy level, the "other" is invested with racial hatred. This "other" can be anyone - immigrants, 
gays, HIV-positive people, infidels, anyone. It is an empty category. A destructive representation is constructed that poisons the world around it and the aggressor feels an incessant need to defend it. Werner Bohleber, who has worked extensively on antisemitism, far-right extremism, xenophobia and fundamentalism, argues that this paranoid-schizoid approach of the world leads to a reversal of roles of victim and victimiser. ${ }^{27}$ It is through this mechanism that Golden Dawn followers transform immigrants from victims to victimisers and so persuasively spread the fear that Greek society is supposedly in great danger.

Immigrants have a preferential place in Golden Dawn's discourse and its activities. With the economic and political crisis, and the lack of integrated policy measures towards immigration (admittedly a very difficult task), it is easy to understand why and how Golden Dawn exploited the fear and aversion towards the alien "others" and managed to convince a big part of conservative voters that immigrants are foreign bodies that need to be expelled. For Golden Dawn cadres and followers, immigrants are pollutants that inhibit the imagined community from remaining pure and homogeneous. It is telling that Ilias Kasidiaris, a Golden Dawn MP and party spokesperson, labelled immigrants as "waste" while speaking in parliament. ${ }^{28}$ According to Mary Douglas, waste is "matter out of place" occupying a denigrated, subordinate position within a spatial taxonomy dominated by binaries - clean and dirty, wanted and rejected, inside and outside. ${ }^{29}$ Waste is always to be found on the side of the subordinate pole of these binaries. Golden Dawn supporters, by turning against immigrants, reaffirmed themselves through a narcissistic reflection of their sameness and a fantasy of purity and cleanliness. This narcissism repels the kind of difference that threatens the unity of the national group. Purity can only be achieved through exclusion. Thus, one can easily understand why the food distribution and blood donations organised by Golden Dawn exclusively for Greek citizens are so appealing to its members. Participation in idealised, pure communities and violent pogroms feed into each other.

Under such conditions the "other" is constructed as a partial object void of subjectivity. The destruction of subjectivity contributes to the sadistic pleasure associated with violence. There is an abundance of images that reveal the faces of Golden Dawn perpetrators glowing with fascination in attacking immigrants. The discourse of its cadres and followers is replete with degrading and humiliating portrayals of immigrants; they derive pleasure in denigrating them, which transpires into an ecstatic euphoric feeling. ${ }^{30}$

\section{Democratic deficit}

Freud underlines that when evil is not condemned by society, raw and wild impulses are let loose. I contend that "evil" in Greece today is related to the prevailing democratic deficit that has provided fertile soil for the burgeoning of Golden Dawn. Extensive corruption, partocracy, lawlessness, the intensification of social inequalities, the delegitimisation of politics, an irresponsible mass media, the unchallenged ease with which the conservative New Democracy and socialist Pasok parties formed a coalition government with Laos, the then softer version of an extreme right-wing party; the facility with which the current radical left Syriza formed a coalition with the populist, rightwing, 
nationalist, anti-European Independent Greeks (Anel) party - all have contributed to a democratic deficit. While the mood as regards public confidence changed after the January 2015 general election, it quickly receded to the older pattern of scepticism and distrust.

The causes of democratic stagnation are deep rooted in historical, political and social parameters and such an analysis is beyond the scope of this article. The fact, however, is that this "evil" awaits a confrontation. Meanwhile, primitive impulses are channelled into group formations such as Golden Dawn. The deep contestation of democracy through the violation of human rights, the practice of violence, as well as the contempt for the rule of law and of the parliamentary order that have characterised Golden Dawn's discourse and practices have reinforced a vicious circle that has drawn society towards cultural regression.

The democratic deficit impedes reflective practices and at a time of a multifaceted crisis, such as the one we are currently experiencing, it can easily turn to collective mechanisms of repression as well as to extremist, violent and nondemocratic solutions.

Yet September 2013 marked a turning point for Golden Dawn. The fatal stabbing of a leftwing rapper by a senior cadre marked the beginning of the unveiling of the political-criminal activities of the party and prompted a major investigation. Michaloliakos, a number of cadres and MPs were detained or held on remand for membership of a criminal organisation. The prosecutor who handled the case accused the suspects of murder, weapon offences and multiple attacks on immigrants, leftists and gays over a period of more than 30 years. He recommended that out of the total 81 persons accused, 67 should face justice. In April 2015, 69 defendants, including Michaloliakos and all the other 17 Golden Dawn MPs elected in June 2012, were put on trial. They are accused of not upholding the functioning of the democratic order and of founding a criminial organisation. The trial is likely to last over a year.

The extremists saw their support drop but not as much as one would have expected it. In many polls they still rank third.

\section{NOTES}

1 "The annual survey of Public Issue on Institutions," Public Issue, 13 Nov 2015, accessed 12 Jan 2015, http://www.publicissue.gr/en/1938/institutions-2014/.

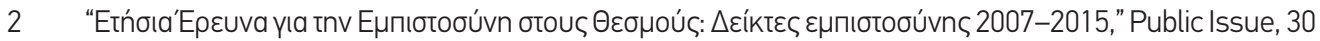
Nov 2015, accessed 26 Jan 2016.

3 "Public Opinion in the European Union," Eurobarometer 75, Spring 2011, accessed 12 Jan 2015, http:// ec.europa.eu/COMMFrontOffice/PublicOpinion/index.cfm/Survey/getSurveyDetail/instruments/ STANDARD/surveyKy/1019.

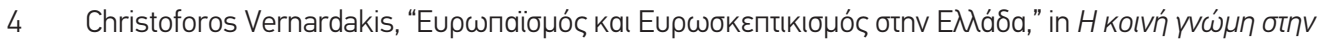

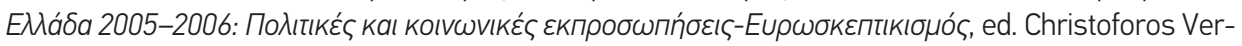
nardakis (Athens: Savvalas, 2007), 147-64. 


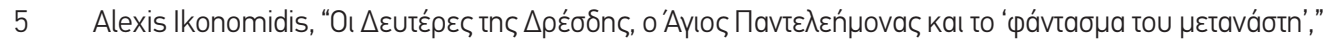
Chronosmag 20 (2014), http://www.chronosmag.eu/index.php/es-e-ese-g-pl-fs-s.html.

6 Aristos Doxiadis and Manos Matsaganis, National Populism and Xenophobia in Greece, Counterpoint, accessed 12 Jan 2016, http://counterpoint.uk.com/publications/national-populism-and-xenopho-

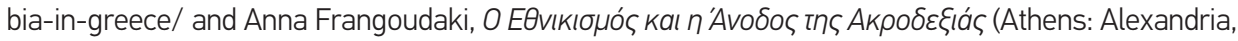
2013).

7 For similar concerns and the rationale explaining extreme cultural violence and aggression resorting to psychoanalytic concepts, see Nancy J. Chodorow, "The enemy outside: thoughts on the psychodynamics of extreme violence with special attention to men and masculinity," Journal for the Psychoanalysis of Culture and Society 3/1 (1998): 25-38.

8 Stavrakakis also uses the notion of the assumption of shame and guilt caused by the indebtedness the Greek people are made to feel, arguing that credit and debt is something that goes far beyond economics and involves subject formation at the most profound level. In his analysis, he uses Lazzarato's account in "The Making of the Indebted Man" in connection with a psychoanalytic twist. "Debt society: Greece and the future of post-democracy," Radical Philosophy 181 (2013): 33-38.

9 David Levine, "Identity, the group and the social construction of reality," Journal for the Psychoanalysis of Culture and Society 4/1 (1999): 81-91.

10 Ibid.

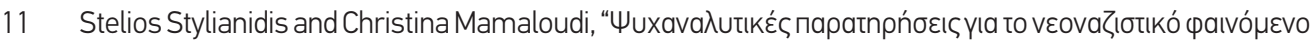

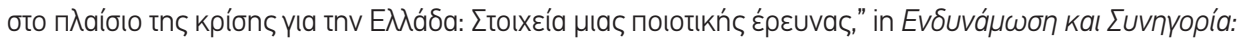

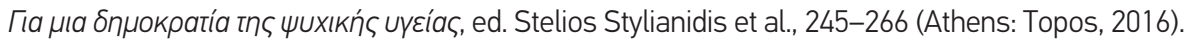

12 For further elaboration of enactment of body politics and more specifically on the role of sound contributing to collective creation of "affirmative resonance" in large-scale Nazi public events, see Carolyn Birdsall, Nazi soundscapes: sound, technology and urban space during Nazi Germany (Amsterdam: Amsterdam University Press, 2012).

13 Étienne Balibar, "Homo nationalis: an anthropological sketch of the nation form," in We, the people of Europe? Reflections on transnational citizenship, trans. James Swenson, 11-30 (Princeton: Princeton University Press, 2004).

14 Berlin 1933 - Der Weg In Die Diktatur. Sonderausstellung, accessed 12 Jan 2016, http://www.topographie.de/aktuelles/news/nc/1/browse/1/nid/berlin-1933-der-weg-in-die-diktatur-sonderausstellung $/ \mathrm{y} / 2013 / \mathrm{m} / 01 / \mathrm{d} / 31 / \mathrm{bp} / 56 /$.

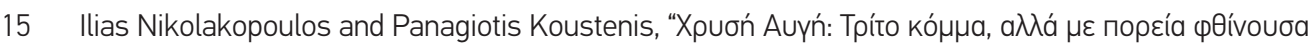

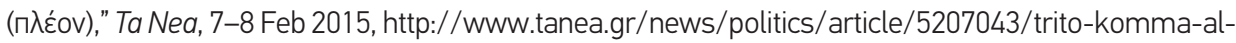
la-me-poreia-fthinoysa-pleon/.

16 Otto F. Kernberg, Internal world and external reality (New York: Jason Aronson, 1980).

17 Helena Klímová, "The false we/the false collective self: a dynamic part of the social unconscious," in The social unconscious in persons, groups, and societies. Vol 1: Mainly therapy, eds Earl Hopper and Haim Weinberg (London: Karnac, 2011), 187-208.

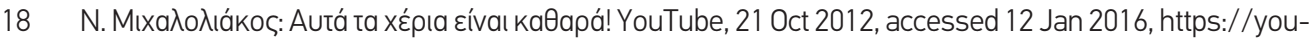
tu.be/Jh5-c7liGe8.

19 Vamık Volkan, “Large-group identity: Border psychology and related societal processes," Mind and Human Interaction 13/1 (2003): 49-76. 
20 Thalia Dragonas, "Mirror representations of national identity: Greece and Turkey," in Contemporary theorizing in psychology: global perspectives, eds Aydan Gülerce et al. (Concord, Ontario: Captus University Publications, 2005), 365-75.

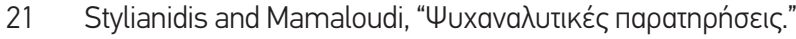

22 Donald Moss, ed., Hating in the first person plural: psychoanalytic essays on racism, homophobia, misogyny, and terror (New York: Other Press, 2003).

23 Sigmund Freud, Group psychology and the analysis of the ego, trans. James Strachey (New York: Boni and Liveright, 1922).

24 Melanie Klein, "Notes on some schizoid mechanisms," International Journal of Psycho-Analysis 27 (1946): 99-110.

25 Ibid. Wilfred R. Bion, Experiences in groups, and other papers (London: Tavistock, 1961).

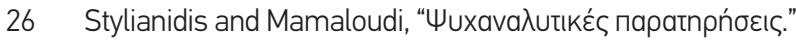

27 Werner Bohleber, "The presence of the past: xenophobia and rightwing extremism in the Federal Republic of Germany: Psychoanalytic reflections," American Imago 52/3 (1995): 329-344.

28 Hellenic Parliament, Plenary Proceedings, 23 Aug 2012, accessed 12 Jan 2016, http://www.hellenicparliament.gr/Vouli-ton-Ellinon/ToKtirio/Fotografiko-Archeio/\#9d80044b-a391-45e5-89ec-64ddec$\mathrm{d} 4 \mathrm{ecbc}$. This brings to mind the representation of Jews as gutter rats in Nazi propaganda films and rhetoric, as discussed by Martin Thom in an article on projection in which opponents were characterized as shitty, nauseating and their ideas as spew, vomit, etc. Martin Thom, "Anti-racism - infections of language," Wedge 3 (1978): 14-22.

29 Mary Douglas, Purity and danger: an analysis of concepts of pollution and taboo (London: Routledge and Kegan Paul, 1966).

30 Interested readers are urged to watch The Cleaners, Konstantinos Georgousis' award-winning documentary, featuring a Golden Dawn candidate (Alekos Plomaritis) referring to immigrants as "subhumans" and "miasma", adding that they would be turned into soap used for washing cars and the pavement. While he speaks in a very sadistic manner, he beams with pleasure, communicating the intoxicating effect power has on him. "Racist, anti-semitic, violent - the true face of Golden Dawn," Channel 4, 5 Mar 2013, accessed 12 Jan 2016, http://www.channel4.com/news/racist-anti-semiticviolent-the-true-face-of-golden-dawn/. 